\title{
In Memoriam of Surin Pitsuwan (1949-2017)
}

\author{
IBRAHIM ABU BAKAR* \& AHMAD SUNAWARI LONG ${ }^{1}$
}

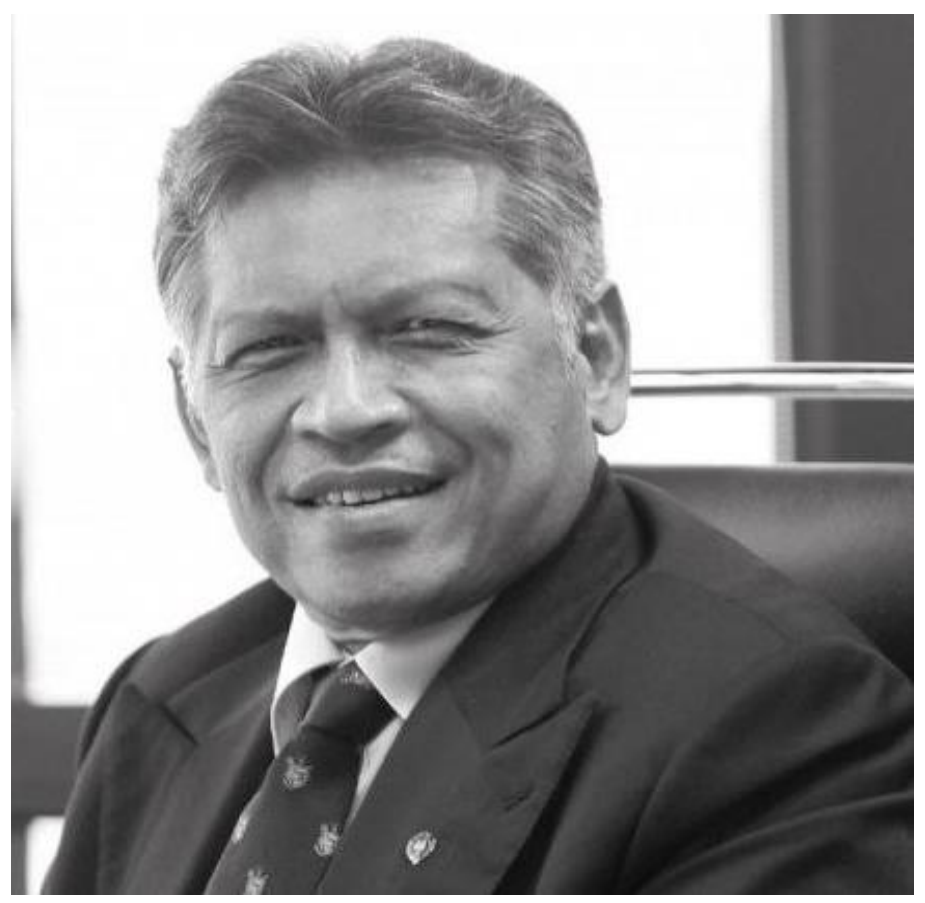

Surin Pitsuwan was born into a Thai, Malay, Muslim family on October 28, 1949 in the Thai southern province, Nakhon Si Thammarat. He received his primary Islamic education from his grand-father, Hj. Yakoob bin Abdul Rauf, a well-known ulama, who was trained in Patani and Mecca, Saudi Arabia and his primary and secondary education in his home province before he was offered the scholarship by the American Field Service (AFS) to study in a college in Minnesota, USA, in 1967-1968. He returned to Thailand and joined Thammasat University in Bangkok. In 1972 he received a bachelor degree in political science from Claremont McKenna College, California, USA.

Surin studied for his master and doctoral degrees at Harvard University. The university awarded him master and doctoral degrees in 1974 and 1982 respectively in the field of political science and Middle Eastern studies. His doctoral thesis topic submitted to Harvard University was Islam and Malay Nationalism. His studies at Harvard University were sponsored by The Rockerfeller Foundation Fellowships as well as the Winston S. Churchill Association.

Surin studied Arabic and Islamic Studies when he joined the American University in Cairo and did a research at the Higher Institute of Islamic Research in Cairo 1975-1977. He became the columnist for the two English newspapers in Bangkok namely the Bangkok Post and the Nation from 1975 until 1992.

1 Ibrahim Abu Bakar*(Corresponding author), Ph.D., former assoc. prof., at Dept. of Theology and Philosophy, Faculty of Islamic Studies, Universiti Kebangsaan Malaysia, 43600 BANGI, Selangor, Malaysia, email: abi@ukm.edu.my; Ahmad Sunawari Long, Ph.D., assoc. prof., at Centre for Akidah and Global Peace, Faculty of Islamic Studies, Universiti Kebangsaan Malaysia, 43600 BANGI, Selangor, Malaysia, email: aslong@ukm.edu.my. 
Surin became a researcher and then a lecturer at Thammasat University from 1977 until 1983 and then from1984 until 1986. In 1983-1984 Surin was in Washington, USA after the American Political Science Association (APSA) offered him the congressional fellowship. While he was the fellow of APSA, he taught Southeast Asian Affairs at the American University in Washington D.C. He returned to Thailand and resumed his teaching position at Thammasat University in 19841986. His last position at the university was The Vice Rector for the Academic Affairs in 1985-1986

Surin did not remain as an academician at that university after he ventured into Thai political arena. He joined the Thai political party, Democrat, in 1986 and became the member of Parliament representing his native province Nakhon Si Thammarat for the Democrat Party. In the same year he was appointed the secretary to the speaker of Thai Parliament. In 1988 Surin was appointed to the post of assistant secretary to Thai Interior Minister. From 1992 until 1995 Surin was the Thai Deputy Minister of Foreign Affairs. He became Thai Minster of Foreign Affairs from 1997 until 2001. His political party Democrat led by Chuan Leekpai was the ruling party in Thailand and Leekpai became the Thai Prime Minister. The Democrat Party later became the main opposition party after the Thai Rak Thai party led by Thaksin Sinawatra became the ruling party and he became the Thai Prime Minister.

In 2004 Surin was named by many countries and international bodies to be the candidate for the post of the United Nations General-Secretary after Kofi Annan ended his tenure in 2004. However, the Thai Government led by Thai Rak Thai Party did not name Surin as the candidate for that UN post. It was probably due to the different political parties between Surin and Takhsin Sinawatra.

After the Thai Military took over the political and ruling power from Thai Rak Thai Party led by Thaksin Sinawatra in 2006, the interim Cabinet of Thailand in July 2017 supported Surin to be a candidate from Thailand for the post of the Asean Secretary-General, and Asean member countries appointed Surin to that post on January 1, 2008 for five years until January 1, 2013.

His experiences in the foreign affairs and the Asean General-Secretary made him known for his ideas and his contributions to Thai and Asean communities. After his tenure ended as the Asean Secretary-General, his Democrat Party was again defeated by Thai Rak Thai Party led by Yingluck Sinawatra, the sister of Takhsin, and she became the Thai Prime Minister for few years before the Thai Military seized the power from her party and she escaped from Thailand to join her brother living outside Thailand.

Surin remained with the Democrat Party that promoted him in the Thai politics and government as the Thai Minister of Foreign Affairs when his party became the ruling party in Thailand for many years. As a politician, when his party lost the ruling power to another political party in Thailand, his public post in the government also disappeared. Political parties play different roles when they become the ruling parties and when they become the opposition parties. This political rule is applied to many democratic countries like Thailand. Surin was up when his political party was up and when his political party was down he was down too.

Even though his political career was down in Thailand, Surin was active in expressing his ideas on human rights, human security, human labor and justice for all communities and individuals. The organizers of the internationals seminars, conferences, discourses or dialogues often invited him to speak in such gatherings. For examples, Surin was invited by the organizers of the $3^{\text {rd }}$ and $4^{\text {th }}$ World Conference on Islamic Thought and Civilization in Perak, Malaysia in 2016 and 2017 respectively. The two conferences were organized by Sultan Azlan Shah University (SASU). In the $3^{\text {rd }}$ conference in 2016, Surin spoke on global peace. In the $4^{\text {th }}$ conference, Surin spoke on love, hate and extremism. 
On September 27, 2017, Surin became the invited guest speaker to the Chancellor Tuanku Muhriz 2nd Lecture, held in the main hall, Dewan Canselor Tun Abdul Razak (DECTAR), Universiti Kebangsaan Malaysia (UKM) and he spoke on good governance and challenges for the Asean community. Prior to that, in the late 1980s, he was invited as the guest speaker to the International Seminar on Islam at ASEAN Institutes of Higher Education, organized by the Faculty of Islamic Studies, Universiti Kebangsaan where the both writer and Editor-in-Chief of the IJIT (International Journal of Islamic Thought) were the committe members and liason officers of the seminar.

In October 2017, Surin was the invited guest speaker by Astroawani (Malaysian local news network) its program named Asean Integrity Dialogue and he spoke on reinventing good governance through universal values. Prof. Dr. A. Murad Merican from Centre for Policy Research and International Studies of Universiti Sains Malaysia (USM) in Penang remembered Surin as a scholar and Asean internationalist as well as a "statesman, and diplomat extraordinaire." (New Straits Times, Dec.3, 2017). Prof. Murad met Surin personally when he attended the $4^{\text {th }}$ World Conference on Islamic Thought and Civilization (WCIT) in Perak, Malaysia in 2017 and spoke to him about the plans of his centre at USM.

Former staff of International Labor Organization (ILO) based in Bangkok in 2002, Rueben Dudley who met Surin in that year in Bangkok remembered Surin as "An intellectual, scholar, diplomat, politician, writer and speaker par excellence and above all, a man of uncompromising integrity and a wonderful gentleman." For Dudley, Surin's legacy was based on "the principles of honesty, equality, the common good, justice, security, reconciliation and peace that he stood for and exemplified." (The Sundaily, Dec. 26, 2017).

Surin wrote a book, Islam and Malays Nationalism: A Case Study of Malay-Muslims of outhern Thailand (1985). He has been conferred 13 honorary doctorate degrees, including from University of Bristol (UK), Claremont McKenna College, the National University of Malaya (UKM) University Purta Malaysia (UPM), Universiti Sultan zainal Abidin (UniSZA) and University of Malaya (UM). He also was a Visiting Professor, an Adjunct Professor and a Visiting Fellow at the Graduate Institute for Policy Studies, Tokyo, University of Nara, Japan and University of Malaya. In 2015, Surin has been awarded the Honarary Darjah Panglima Setia Mahkota (PSM) by His Majesty, Tuanku Abdul Halim Muadzam Shah which carries the title Tan Sri.

Surin died in Bangkok on November 30, 2017 at a hospital in Bangkok and his remain was buried in his native province. He left behind his wife, Alisa and three children, Fricli Pitsuwan, Muhammad Fuake Pitsuwan and Hussani Pitsuwan. His death was due to the serious heart attacks when he was at his home in Bangkok preparing to attend the Halal Seminar at BITEC (Bangkok International Trade and Exhibition Centre) in Bang $\mathrm{Na}$, Bangkok as the invited guest speaker.

As a Muslim man who lived and died in his religion Islam, Surin was one of the great Thai Malay Muslims who contributed to human beings in general and to the Asean communities in particular in many capacities as remembered by Prof. Murad and Rueben Dudley as cited above. May Allah, the God for all Muslims, place Surin Pitsuwan among His good, religious, obedient and dedicated servants.

"Without inclusivity and equity, our community will be sitting on a very shaky and flimsy foundation because at the end of the day, any society, any community, any civilization will be judged on the basis of how you treat members of your society, your community, your civilization. So if a man, a woman, a girl, a boy with a disability is left out of the efforts of development, that society or community will be much less in its achievements and measurements of how well that society has performed ... The worst form of exploitation is to be left languishing in the situation of no opportunity, no 
chance, no care, and no compassion. Then we try to enhance the capacity of people, teaching people to fish rather than giving them fish." Dr. Surin Pitsuwan, APCD Newsletter . Vol. 33. Oct 2010.

https://doi.org/10.24035/ijit.13.2018.013 